\title{
Monoplacophorans and the Origin and Relationships of Mollusks
}

\author{
David R. Lindberg
}

Published online: 15 April 2009

(C) The Author(s) 2009. This article is published with open access at Springerlink.com

\begin{abstract}
The story of the discovery and study of the Monoplacophora (or Tryblidia) and how they have contributed to our understanding of the evolution of the Mollusca highlights the importance of integrating data from the fossil record with the study of living forms. Monoplacophora were common in the early Paleozoic and were thought to have become extinct during the Devonian Period, approximately 375 Mya. In the mid 1950s, they were recovered from abyssal depths off of Costa Rica and were immediately heralded as a "living fossil." The living specimens confirmed that some of the organs (kidneys, heart, and gills) were repeated serially, just like the shell muscles that had been observed in fossil specimens. This supported the hypothesis that they were closely related to other segmented organisms such as annelids and arthropods. Today, there are 29 described living species and a growing body of work examining their anatomy, phylogeny, and ecology. Additional fossil specimens have also been discovered, and what was once thought to be a possible missing link between annelid worms and mollusks now appears to be a highly specialized branch of the molluscan tree that tells us little about the ancestral mollusk condition. However, some assumptions and generalizations from those early days still remain — such as the abyssal nature of the living species. A large part of the evolutionary history of the lineage remains to be discovered and will likely prove more complicated and interesting than afforded by the living fossil designation.
\end{abstract}

D. R. Lindberg

UC Museum of Paleontology, University of California,

Berkeley, CA 94720, USA

D. R. Lindberg $(\square)$

Department of Integrative Biology, University of California,

3060 VLSB, MC-3140,

Berkeley, CA 94720-3140, USA

e-mail: drl@Berkeley.Edu
Keywords Monoplacophora $\cdot$ Tryblidia $\cdot$ Mollusca $\cdot$ Evolution · Limpet

The story of the discovery of living Monoplacophora (or Tryblidia) and the study of both fossil and living species has greatly shaped our ideas of the evolution of the Mollusca, and this body of work highlights the importance of integrating data from the fossil record with the study of living forms. However, it also provides important examples of the caution that must be exercised when studying lineages across such broad expanses of the history of life. Monoplacophorans are one of the least known members of the living Mollusca as compared to the other groups such as Gastropoda (snails), Bivalvia (clams), and Cephalopoda (octopus and squids). All of these molluscan groups, as well as monoplacophorans, are also well represented in the early Paleozoic Era, and it was there that the monoplacophorans apparently reached their greatest abundance and diversity.

The name Monoplacophora places these animals in a group of mollusks referred to by paleontologists as the placophorans or "plate" mollusks. Members of this level of morphological organization (or grade) typically have elongate bodies and either a single shell (Monoplacophora), seven, eight, or up to 17 plates (Polyplacophora) or lack plates altogether and instead have calcium carbonate spicules (Aplacophora). In the 1990s, new fossil discoveries in the Cambrian of Greenland and later in China revealed an elongate animal with both spicules and platesthe Halkieria (Conway Morris and Peel 1990). Some paleontologists and zoologists have argued that these animals are mollusks and therefore are yet another representative of the placophoran grade of organization. Others argue that while they are closely related to mollusks and other lophotrochozoan groups such as annelid worms 
or perhaps brachiopods, they are not members of the Mollusca (see Vinther and Nielsen 2005; Caron et al. 2006; Butterfield 2006 for a sampling of both pro and con arguments).

\section{Fossil Monoplacophora}

Monoplacophora were first known from the fossil record and until the mid 1950s were thought to have become extinct during the Devonian Period, approximately 375 Mya. In an 1880 listing of Silurian fossils, G. Lindström proposed the name Tryblidium for some limpet-like mollusks with six pairs of muscle scars on the interior surface of the shell (Angelin and Lindström. 1880; Fig. 1). By the beginning of the twentieth century, monoplacophorans were placed in their own superfamily (Tryblidiacea) and considered by most paleontologists (e.g., Whitfield 1889; Cleland 1903; von Zittel 1913) to be gastropod mollusks closely related to the living patellacean limpets (Patella, Lottia - the "true limpets"). However, an alternative view had been expressed in the early 1890 s by one of the great, late nineteenth century American naturalists, William H. Dall. Dall (1893) raised the question of possible convergence in limpet-like shell morphologies and made a surprising prediction about tryblidiacean affinities. Dall had discovered very different types of feeding structures (radulae) in deep-sea limpet species with virtually identical shells. This observation impressed on Dall just how strong shell convergence could be in mollusks, especially when limpets were involved, and he reasoned

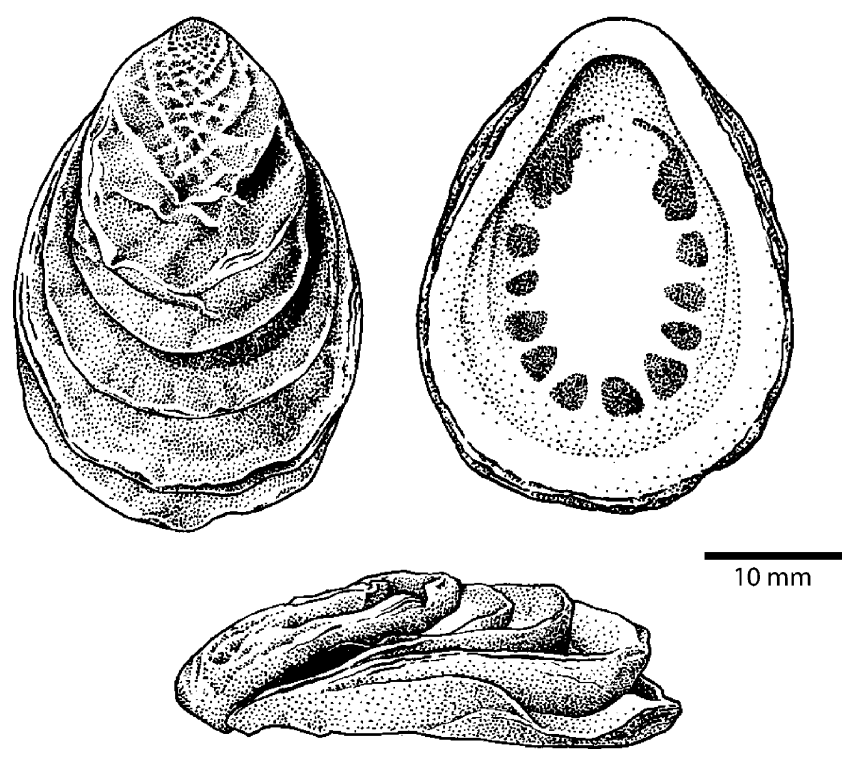

Fig. 1 Tryblidium reticulatum Angelin and Lindström 1880. Silurian (Wenlock); Gotland, Sweden. From Treatise on Invertebrate Paleontology, courtesy of The Geological Society of America and The University of Kansas (C)1960
Fig. 2 Stratigraphic occurrence and generic diversity of Monoplacophora with paired muscle scars (Tryblidacea). Although living species have been allocated to numerous genera, they are represented here by a single lineage. Data from Sepkoski (2002) and The Paleobiology database (http://paleodb.org/)

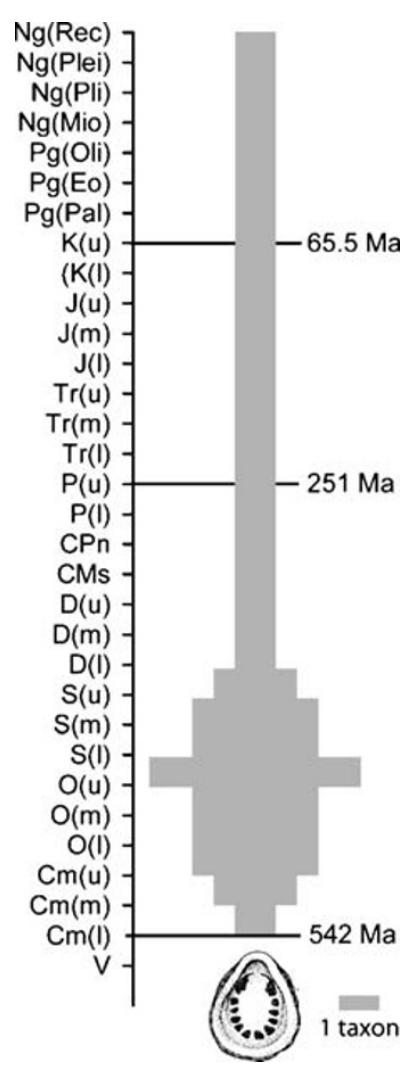

that if such convergence were possible in living species, fossil taxa would likely present similar problems. Moreover, the correct allocation of species in the fossil record could be even more difficult the deeper the time and the more unfamiliar the taxa were to living ones. He singled out the similarity of shells of Silurian Tryblidium with living patellacean limpets and warned that it was dangerous to conclude that Tryblidium anatomy would have been similar to living patellids - "it is almost inconceivable that the Silurian form should have any closely allied recent representative" (Dall 1893:287). Moreover, the symmetry of the muscle scars in the Tryblidium fossils suggested to Dall "...a peculiar disposition of the organs which might, indeed, have paralleled in some particulars the organization of some of the Chitons of that ancient time." It would be 45 years until a similar observation was repeated by Wenz (1938) and another 18 years after that until the recovery of living monoplacophorans confirmed Dall's insight into the non-gastropod like affinities of these animals.

Subsequent finds added more fossil species and genera and extended the group back into the Ordovician and Cambrian (Fig. 2). Initially, monoplacophorans were recognized by the presence of multiple, symmetrical muscle scars in patelliform shells, but then multiple muscle scars were also found in high conic shells and also in coiled ones. Whether these fossils are monoplacophorans or gastropods is debatable based on several lines of inference, and there remains some controversy as to what are and what are not 
monoplacophorans in the fossil record (see Signor 1985; Runnegar 1996). For example, whereas Pojeta and Runnegar (1976) and Peel (1991) considered almost all Cambrian cap-shaped taxa as well as the coiled Helcionelloida and some, if not all, of the bellerophontiform taxa to be monoplacophorans, other workers, including Knight and Yochelson (1960), Golikov and Starobogatov (1988), and Parkhaev (2002, 2008), limit the diagnosis of Monoplacophora to cap-shaped taxa and consider the remaining Helcionelloida and bellerophontiform taxa to be members of other univalved or gastropod groups. Because these positions are based on the interpretations of a small suite of muscle insertion characters and cartoonlike reconstructions of possible water-flow patterns, it is difficult to test either position. Further complicating this controversy is the presence of limpets in the Lower Paleozoic with continuous muscle scars (Peel and Horný 1999; see below).

\section{Living Monoplacophora}

The discovery of living monoplacophorans in the 1950s was one of the great biological discoveries of the last century, similar to the discovery of the living coelacanth off the coast of Africa in 1938 and the discovery of the Wollemi Pine in Australia in 1995. Living monoplacophorans were first recovered by the Danish research ship Galathea from a dark, muddy clay bottom at a depth of 3,570 m off the coast of Costa Rica in 1952. Ten living animals and three empty shells were recovered, and like many specimens collected during deep-sea expeditions, they were preserved on board ship and set aside for study upon return to mainland laboratories where the significance of these specimens was first realized. Whether the official discovery of living monoplacophorans dates from the collection of Neopilina galatheae in 1952 or the formal description by Hennig Lemche in 1957, at least four living monoplacophoran shells had been collected prior to 1900, but their significance went unrecognized. Neopilina goesi was first dredged in 1869 off the Virgin Islands in the Caribbean (Warén 1988) and Rokopella euglypta (Dautzenberg and Fischer 1897), Veleropilina reticulata (Seguenza 1876), and Veleropilina zografi Dautzenberg and Fischer (1896) were all originally described as patellacean limpets. After the discovery of $N$. galatheae, additional species were soon discovered, and today there are 29 described taxa distributed worldwide between 175 and 6,400 $\mathrm{m}$ (Haszprunar 2008).

The observations of Dall, Wenz, and Knight had suggested that the paired muscles of Tryblidium might be a primitive character state aligning monoplacophorans with chitons, but what about the rest of the anatomy that could now be ascertained from the newly discovered specimens? Lemche and Wingstrand (1959) and later (Wingstrand 1985) undertook a detailed anatomical study of the Galathea specimens. They found that the monoplacophoran animal had a poorly defined head like a chiton but with an elaborate mouth structure on the ventral surface (Fig. 3). The mouth was surrounded by an $\wedge$-shaped, thickened anterior lip and post-oral tentacles that came in a variety of morphologies and configurations. Below the head was the oval foot and in the mantle groove, between the lateral sides of the foot, and the ventral mantle edge, were five to six pairs of widely spaced gills similar to the pairing of the shell muscles (Fig. 3).

When they examined the specimens, they found a typical molluscan gut with foregut, stomach, paired digestive glands, and a coiled hindgut. There were two pairs of gonads instead of the typical single pair, and multiple paired excretory organs, some of which connected to the gonads and served as ducts for spawning gametes. A bilobed ventricle lay on either side of the rectum and was connected via a long aorta to the head region and also connected to two pairs of atria, which in turn were connected through sinuses to the gills and posterior excretory organs. The nervous system was laterally (but not ventrally) ladder-like as in chitons but had more prominent anterior ganglia. As reconstructed from the fossils almost 75 years earlier, paired muscle bundles enclose the visceral mass. The monoplacophoran radula, another structure often assessed for its primitive and derived characteristics, was docoglossate, with a rachidian tooth, three pairs of lateral teeth, and two pairs of marginal teeth. The lateral teeth were in a stepped configuration with the first and second pair of lateral teeth lined up with the rachidian tooth and the third lateral pair slightly posterior and lateral of first two pairs, and the cusps of the inner most marginal tooth were frilled. But, rather than being similar to chitons, which also have a docoglossate radulae, it was most similar to the radulae of some patellacean gastropods (Fig. 4).

The shell structure of the Galathea specimens and fossil monoplacophorans was studied by Schmidt (1959), Erben et al. (1968), Meenakshi et al. (1970), McLean (1979), and Hedegaard and Wenk (1998). In Recent species, the outer surface of the shell is covered by a thin periostracum, and under the periostracum is an outer prismatic shell layer and an inner nacreous layer - the traditional primitive shell structure configuration. This same configuration of shell layers is also present in fossil monoplacophorans.

One of the most controversial anatomical structures described by Lemche and Wingstrand were the paired "dorsal coeloms" that were thought to connect with the anterior excretory organs and were topographically similar to the fused gonads in chitons. Because other living mollusks do not have distinct coelomic spaces, these structures suggested an even more primitive character than the other paired structures and a character that might align 
Fig. 3 Ventral view of tryblidacean monoplacophoran showing general anatomy and gill morphology and gill stem anatomy. Redrawn from Lemche and Wingstrand (1959)

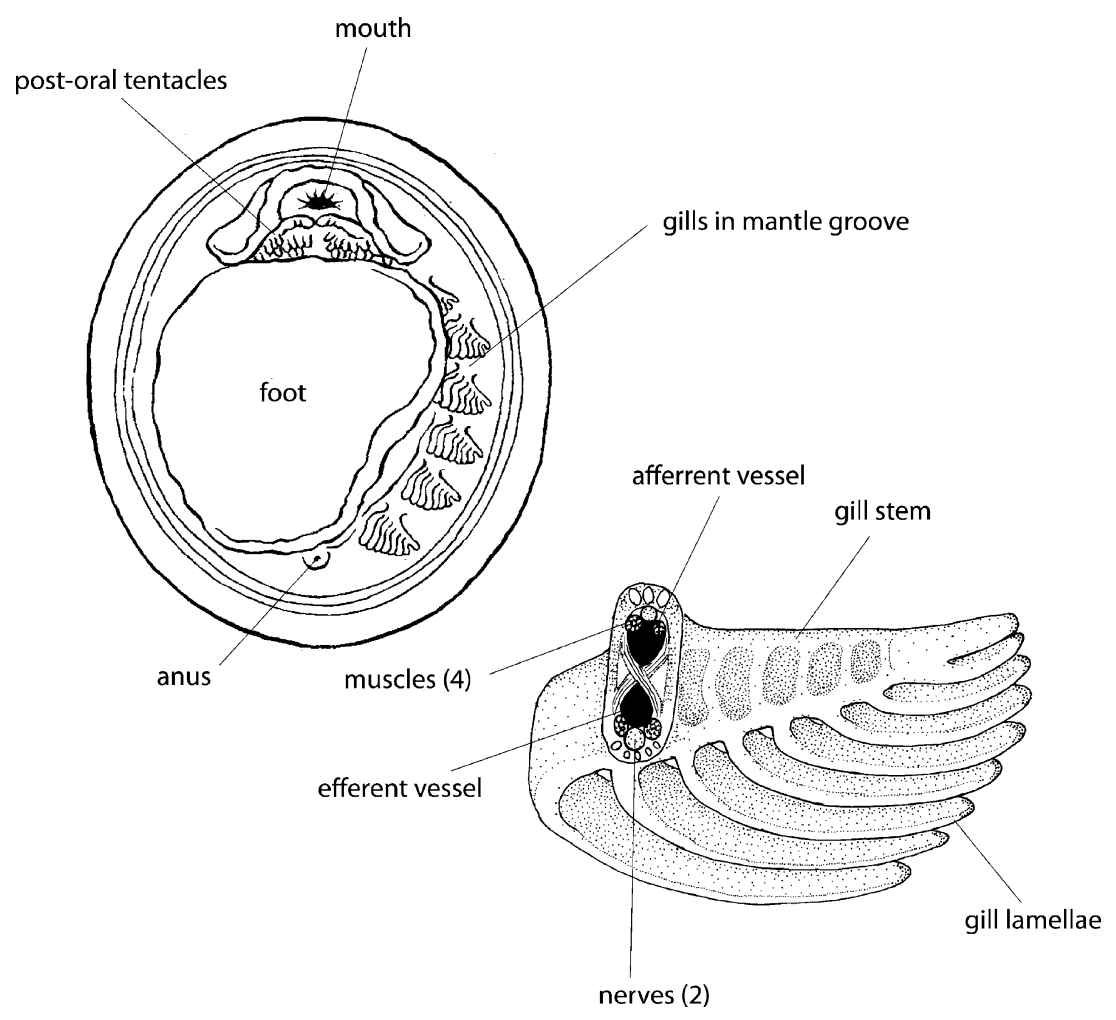

the monoplacophorans even closer to the coelomate annelid worms. However, later studies found that these structures were associated with the foregut and were actually esophageal pouches (see Haszprunar and Schaefer 1997a).

Another misinterpretation occurred with the monoplacophoran protoconch-the larval shell. Lemche and Wingstrand (1959) illustrated a spirally coiled "protoconch" on a single specimen of $N$. galatheae. However, all subsequent Recent monoplacophoran shells that have retained this earliest ontogenetic stage of the shell and all known Paleozoic examples have bulbous protoconchs. As suggested by Bouchet et al. (1983), Lemche and Wing-

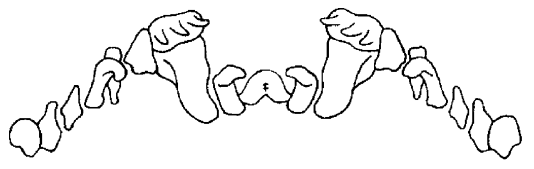

Polyplacophora

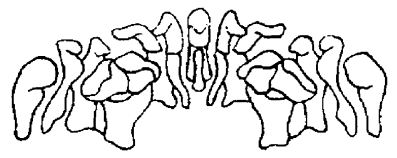

Patellidae

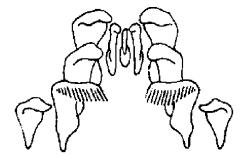

Monoplacophora

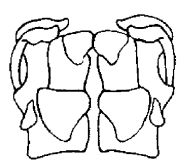

Lottiidae

\section{Gastropoda}

Fig. 4 Comparative morphology of generalized Polyplacophora, Monoplacophora, and Patellogastropoda radular dentitions. Redrawn from Lindberg (1988) strand's observation was in error and the spirally coiled structure actually an area of shell repair. Figured bulbous protoconchs range in size from $123 \mu \mathrm{m}$ to $150 \mu \mathrm{m}$ in diameter, and this size compares favorably with the known mature egg diameters of $200-350 \mu \mathrm{m}$ for the taxon (Gonor 1979; Haszprunar and Schaefer 1997a).

\section{Monoplacophorans as Living Fossils}

The term living fossil emphasizes a taxon that appears little changed since its initial appearance in the fossil record. In addition, these taxa typically have survived a large portion of geological time and have low living diversity. Because they so closely resemble their putative fossil ancestors, it is assumed that they have been in morphological and/or physiological stasis and therefore retain primitive characters for their group. Lastly, this remarkable survival is often coupled with their occurrence in some sort of refugial habitat. Monoplacophorans fit these criteria well. They have retained the simple limpet shell morphology with the same shell microstructure; the shell musculature appears unchanged over a half a billion years; the living representatives have both low diversity and abundances; and they are found at abyssal depths in the deep sea.

So, as living fossils, what might they tell us about molluscan relationships? One of the main questions 
surrounding molluscan relationships has been the identity of the sister taxon of the Mollusca - the group that shares the last common ancestor with the Mollusca. Two major positions have been taken - one aligning the flatworms with the Mollusca and the other the annelid worms. Because segmentation is such a defining character of the annelids, the multiple paired muscles of chitons and fossil monoplacophorans was suggestive of the possibility of segmentation in the ancestral molluscan lineage as well. However, living chitons with a single pair of kidneys, digestive glands, gonoducts, etc. did little to resolve the argument. Thus, the discovery of living Monoplacophora with their multiplication of several organ systems and structures (gills, gonads, kidneys, etc.) was interpreted as evidence for a segmented molluscan ancestor (e.g., Lemche 1959a, b; Lemche and Wingstrand 1959; Götting 1980; Wingstrand 1985). However, others (e.g., Steinböck 1963; Vagvolgyi 1967; Salvini-Plawen 1972, 1981, 1985, 1991; Haszprunar 2008) argued against this interpretation and for an independent development of duplicated organs and structures.

As pointed out by Haszprunar (2008), the Monoplacophora have yet to be subjected to a rigorous cladistic analysis, and the limited molecular data currently available produce an unexpected outcome, with the monoplacophorans residing within the polyplacophorans (Giribet et al. 2006). Most morphological analyses place the Monoplacophora at or near the base of the conchiferan clade [=monoplacophorans, bivalves, gastropods, scaphopods, and cephalopods] (Wingstrand 1985; Runnegar 1996; Salvini-Plawen and Steiner 1996; Waller 1998; Haszprunar 2000; Haszprunar et al. 2008). Cladistic analyses of gastropod relationships by Ponder and Lindberg (1996, 1997) used both Polyplacophora and Monoplacophora as outgroups, and while not specifically addressing character state polarity within the Monoplacophora, the results of these larger scale analyses identified numerous unique or autapomorphic character states relative to the polyplacophorans and basal gastropods (Ponder and Lindberg 1997: Appendix 3). Schaefer and Haszprunar (1997b) also came to a similar conclusion and provided a listing of 11 autapomorphic character states, which they argued identified the Monoplacophora as an early, but highly modified branch of the molluscan tree.

Several lines of evidence suggest that the monoplacophorans appear to be primitive because many of their systems and character states appear to exhibit a developmental state referred to as paedomorphosis. Changes in the timing of the development of organs and structures is a process called heterochrony (Gould 1977), and the forms of expression have been described qualitatively and quantitatively by de Beer (1951), Gould (1977), Alberch et al. (1979), McKinney and McNamara (1991), Zeldrich (2001), and references therein. In summary, heterochrony produces two forms of morphological expression: paedomorphosis, the retention of ancestral juvenile characters by later ontogenetic stages of descendants and peramorphosis, new descendant characters produced by additions to the ancestral ontogeny. The role of heterochrony in biotic evolution received renewed interest and study since the appearance of Gould's (1977) seminal treatment of ontogeny and phylogeny.

Paedomorphic mesodermal structures Wingstrand's (1985) polarity for putative monoplacophoran metamerism required degradation from the almost complete symmetry of the annelid condition to the incomplete correspondence seen in monoplacophorans. As pointed out by Haszprunar (1992) and Schaefer and Haszprunar (1997a), the lack of organ symmetry in the monoplacophorans has important implications for arguments regarding arguments for metamerism in this group. Instead of a linear series of body units, each with similar if not identical features, there is an almost haphazard association of shell muscles, gills, auricles, kidneys, and gonads in the monoplacophorans (Wingstrand 1985; Haszprunar 1992; Haszprunar and Schaefer 1997a; Table 1).

Wingstrand (1985:47) was aware of this and discussed the potential role of the mesoderm in producing this pattern and also identified the critical question-is monoplacophoran "metamerism" pleisiomorphic (primitive) or autapomorphic (uniquely derived)? In other words, is it homologous and shared with the annelids via a common ancestor or is it a unique, derived character of the monoplacophorans? Outgroup comparison (chitons or even aplacophorans) does suggest that the musculature might be pleisiomorphic, but the serial repetition of the other structures is clearly autapomorphic.

There was also a non-correspondence in the direction of the addition of structures during development between Annelida, chitons, and monoplacophorans. Although developmental studies of Monoplacophora are lacking, several authors have made studies of size series within wellcollected species to postulate developmental sequences. For example, Starobogatov (1970) and Moskalev et al. (1983) have noted that that the gills appear and develop from the posterior to the anterior during growth and that the number of leaflets of the individual gills also increased with the size of the animal. Haszprunar (2008) made similar observations of the number and direction of addition of the gills in five species of small monoplacophorans, as well as in the size and developmental state of the gonads in Micropilina arntzi and Laevipilina antarctica and the state of development of the post-oral tentacles. Especially informative was his observation that in a male specimen of L. antarctica, the most anterior gonad was not completely separated and still partially fused with the posterior ones, and small specimens of $L$. antarctica only had four rather than five gills. 
Table 1 Repetition of organs in monoplacophoran species

\begin{tabular}{|c|c|c|c|c|c|c|}
\hline \multirow[t]{2}{*}{ Character } & \multicolumn{6}{|l|}{ Taxon } \\
\hline & $\begin{array}{l}\text { Neopilina } \\
\text { galatheae }\end{array}$ & Vema ewingi & $\begin{array}{l}\text { Micropilina } \\
\text { arntzi }\end{array}$ & $\begin{array}{l}\text { Rokopella } \\
\text { segonzaci }\end{array}$ & $\begin{array}{l}\text { Micropilina } \\
\text { minuta }\end{array}$ & $\begin{array}{l}\text { Laevipilina } \\
\text { antarctica }\end{array}$ \\
\hline Shell size (mm) & 37 & 33 & 0.9 & 0.9 & 1.2 & 3 \\
\hline Shell muscles & 8 & 8 & 8 & - & - & 8 \\
\hline Gills & 5 & 6 & 3 & 5 & 4 & 5 \\
\hline Kidneys & 6 & 7 & 3 & - & - & 6 \\
\hline Gonads & 3 & 2 & 1 & - & - & $2 / 3$ \\
\hline Atria & 2 & 2 & 0 & - & - & 2 \\
\hline Source & $\begin{array}{l}\text { Wingstrand } \\
(1985)\end{array}$ & $\begin{array}{l}\text { Wingstrand } \\
(1985)\end{array}$ & $\begin{array}{l}\text { Haszprunar and } \\
\text { Schaefer (1997b) }\end{array}$ & $\begin{array}{l}\text { Warén and Bouchet } \\
\text { (1990) }\end{array}$ & $\begin{array}{l}\text { Haszprunar } \\
(2008)\end{array}$ & $\begin{array}{l}\text { Schaefer and } \\
\text { Haszprunar (1997) }\end{array}$ \\
\hline
\end{tabular}

Format modified from Wingstrand (1985) and Haszprunar and Schaefer (1997a)

En-dash (-) not known

In the outgroup Polyplacophora, Russell Hunter and Brown (1965) demonstrated that chiton gills are added posteriorly (Lepidopleurida) or anteriorly (Chitonida) and often exhibit asymmetric conditions. They argued that this occurs to meet increased respiratory needs as the animal grows and surface to volume ratios increases, and the multiplication of gills reflected functional needs rather than the vestiges of an ancestral condition. A similar scenario may also be applicable for monoplacophorans, and the anterior addition of gills in monoplacophoran suggests a polarity for the addition of structures (i.e., duplication) and may provide insights into the causality of serial repetition in monoplacophoran organs. However, it may not be the gills that are providing the additional respiratory surfaces.

The monoplacophoran gills are located in the mantle groove surrounding the foot; there are between three and six pairs depending on the taxon, and the structure of the central axis is similar to that found in the polyplacophorans (Fig. 3). However, the gill retractor muscles are more organized and defined in the monoplacophoran gill as compared to the polyplacophoran gill. In addition, the monoplacophorans gills are densely ciliated and lack squamous epithelium that distinguishes the respiratory zone of other molluscan gills (Schaefer and Haszprunar 1997; see also Lindberg and Ponder 2001: Fig. 6).

Lowenstam (1978) filmed and photographed living monoplacophorans showing the gills vibrating, apparently to move water through the pallial groove-vibrating gills are unknown in other mollusks where ciliary action, sometimes assisted by muscular contractions, moves water over the gill surfaces (Haszprunar 1992). In a subsequent paper, Lowenstam (1978) mentioned that movements of the shell were accompanied by an acceleration of gill beating, but did not further elaborate on this atypical function for these supposed respiratory structures. Lowenstam's observation of beating gills led Lindberg and Ponder (1996) to restudy the arrangement of the kidneys, gills, and auricles of $N$. galatheae (Lemche and Wingstrand 1959: Fig. 144) and to propose a new functional and evolutionary scenario for the monoplacophorans "gills".

Lindberg and Ponder (1996) proposed that the respiratory surfaces of living monoplacophorans are the kidneys, not the gills. In the Monoplacophora, the excretory organs lie above the mantle groove, in juxtaposition with both the venous and arterial mantle sinuses, each associated with a gill. The placement of the excretory organs in the roof of the mantle groove rather than within the visceral mass is a substantial departure from their arrangement in the supposed sister taxon Polyplacophora (Fig. 5) and is also an additional synapomorphy, which unites the Conchifera (Lauterbach 1983). The movement of the kidneys with their rich blood supplies into close contact with the mantle cavity provides another potential respiratory surface. In some bivalves, plicate canals at the posterior end of the excretory organs serve as important respiratory sites (White 1937), and gastropod respiratory systems vary from ones in which most of the blood goes directly to the gills to those where the kidney is the main respiratory surface (Hyman 1967; Haszprunar 1988).

The size and number of vessel connections between the auricles, kidneys, and gills of $N$. galatheae suggest the kidneys are important respiratory sites in monoplacophorans. Whereas each gill has a single connection with the auricle, the kidneys typically have two connections. Although unlabeled, Lemche and Wingstrand (1959) illustrated over 25 connections to the kidneys in $N$. galatheae and only ten with the gills. Thus, anteriorward serial replication of the mesoderm-derived structures (shell 


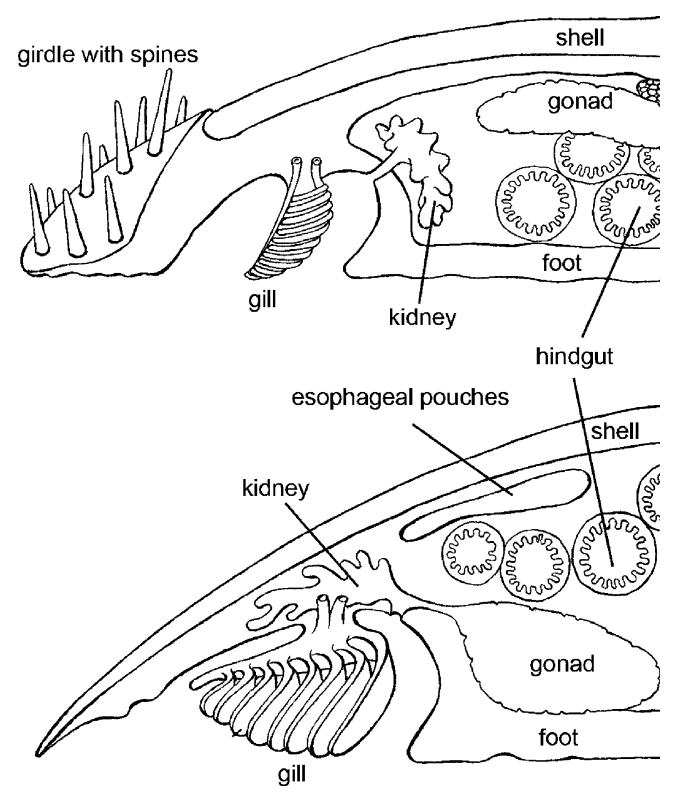

Fig. 5 Transverse sections through the midsection region of a generalized polyplacophoran and monoplacophoran mollusks showing placement of excretory structures and other internal organs. Redrawn from Lemche and Wingstrand (1959)

muscles excepted) in the Monoplacophora could be driven by selection for increasing respiratory surface. The gills or perhaps more correctly, ventilators, are each associated with a nephridial respiratory site which they ventilate. Size and ancestry of a monoplacophoran lineage probably determines the number of respiratory sites (both kidneys and ventilators). Lindberg and Ponder (1996) proposed that heterochronic changes (both paedomorphic and peramorphic), operating primarily on developing mesodermal tissues, led to the addition or deletion of ventilators and respiratory sites. Changes in the timing of formation of kidney rudiments could also produce different numbers of kidneys. And because gonads are also offshoots of the kidney rudiments (Moor 1983), the number of these structures may also have been affected. Schaefer and Haszprunar (1997b) reached a similar conclusion regarding the ventilator function of the gills based on the lack of a distinct respiratory zone on the monoplacophorans gills and comparisons to them to gill and ventilator configurations in other mollusks (see Haszprunar 1992). Whether or not the larger Paleozoic monoplacophorans had primarily respiratory gills or ventilators is not known, but this question might be explored using models that incorporate gas diffusion measurements with volume to surface area ratios.

The outstanding anatomical studies of the brooding monoplacophoran M. arntzi (Haszprunar and Schaefer 1997a) and other species (Schaefer and Haszprunar (1997); Haszprunar and Schaefer 1997b; Haszprunar 2008) demonstrated paedomorphic trends in organ systems of other living monoplacophorans species taxa. M. arntzi is less than a $1 \mathrm{~mm}$ in length and shows numerous reductions and simplifications of "typical" monoplacophoran anatomy. Warén and Hain (1992) reported that the animal lacked post-oral tentacles. Haszprunar and Schaefer (1997a) recounted that although the typical eight pairs of shell muscles are present, there are only three pairs of gills and kidneys and a single pair of gonads. Components of the alimentary system are also reduced and simplified, and the radular cartilages are reduced to a single pair. In contrast, the nervous system appears identical to larger monoplacophoran species. This pattern of modification and reorganization of the kidneys, gonads, and heart and simplification of endodermal alimentary structures, while leaving the nervous system relatively unmodified, is identical to the heterochronic patterns seen in the evolution of brooding in the Patellogastropoda (Lindberg 1983, 1988). Here again, it appears that the combination of mosaic development and dissociation of structures produced by different germ layers has produced mollusks with heterochronic anatomical patterns with some ectodermally derived structures that differ little from their ancestors, endodermally derived structures that have been juvenilized, and mesodermally derived structures that have produced new morphologies.

Although the pedal nerve cords of the brooding species appeared to have little change relative to larger monoplacophoran species, the pedal nerve configuration of monoplacophorans does differ from other mollusks and is likely autapomorphic as well. Lindberg and Ponder (1996) compared polyplacophorans, monoplacophorans, and basal gastropods. In the polyplacophorans, the pedal nerve cords are thick, lie parallel to one another, and have numerous cross-connections. In the vetigastropods, the pedal nerve cords also show this arrangement regardless if the taxon is coiled or limpet-like. In the patellogastropods, the pedal nerve cords are also stout with several cross-connections. However, in the monoplacophorans, the pedal nerve cords are not parallel but arranged in a broad oval, fused posteriorly and have cross-connections to the lateral nerve cords rather than to each other.

Reduction of the radular apparatus The monoplacophoran radula is another structure that shows putative reductions. This includes both the radular dentition as well as the radular support structures that press the dentition against the substrate during feeding. As noted above, monoplacophoran radular dentition is more similar to the gastropod limpets than it is to chitons, cephalopods, or other nontorted molluscan groups.

The number of radular teeth are reduced in the monoplacophoran radula (Fig. 4) compared with polyplacophoran radulae (five teeth flanking the central tooth on each side, compared with eight). In the patellogastropod 
group Patellidae, the number of lateral teeth and plates is about nine on either side of the central teeth. The monoplacophoran radula is reduced relative to the Polyplacophora and the Patellidae, but appears convergent with radulae of the patellogastropod group Lottiidae (Fig. 4).

Stuber and Lindberg (1989) argued that the habitat changes exhibited by Monoplacophora through geological time (see below) required dietary shifts that correlate with particular radular modifications. They concluded that the number and morphology of radular teeth found in Recent monoplacophorans living in deep water habitats could not have been employed effectively by early Paleozoic monoplacophorans, which apparently lived exclusively in intertidal and nearshore habitats, and had become convergent with members of the Lottiidae.

The radula support structure, or odontophore, consists of a pair of hollow, fluid-filled vesicles to which are attached vesicular tissue bands commonly referred to as radular cartilages. In the Monoplacophora, there are two distinct pairs of cartilages: the lateral cartilages and the medial cartilages. Wingstrand (1985) also noted a pair of small cartilages, detached from the medial cartilage in $N$. galatheae. Although monoplacophoran radular vesicles are proportional in size to those found in polyplacophorans, the radular cartilages are substantially reduced in size. For example, although the lateral cartilages of polyplacophorans typically extend almost the entire length of the radular vesicles and the medial cartilages typically half the length, both radular cartilages of the monoplacophoran radular support are confined to the anterior third of the vesicles. Here again is evidence for reduction (or elaboration) in the Monoplacophora relative to the Polyplacophora.

Muscle scars The eight pairs of muscles of the Monoplacophora are the single most diagnostic character of the group and unite fossils and living representatives across half a billion years of time. However, as discussed above, there remains some controversy as to what are and what are not monoplacophorans in the fossil record and especially in the Cambrian (see Peel 1991 and Parkhaev 2008 for overviews). One of the most problematic and controversial groups are the Early Paleozoic limpets with continuous muscle scars (Peel and Horný 1999). These limpets resemble monoplacophorans shells in their overall morphology but have continuous bands of shell attachment muscles rather than the paired muscle scars of monoplacophorans. These muscle patterns are more similar and in some case almost identical to muscle scars found in living gastropods (e.g., Patellogastropoda, Cocculinoidea, Fissurelloidea). One of these taxa is Floripatella rousseaui from the Middle Ordovician of Utah, USA (Yochelson 1988). Yochelson considered this specimen to represent the earliest representative of the Patellogastropoda and therefore a gastropod rather than a monoplacophoran. However, a unique structure preserved on the specimen may provide additional information for interpreting this fossil and determining at least part of the potential range of variation in monoplacophoran musculature.

As unusual as it seems, circulatory patterns are sometimes preserved in fossil limpets. Hickman and Lindberg (1985) described and illustrated how the mantle vein of Recent patellogastropod species produces an impression on the shell interior just anterior of the left shell muscle attachment point. For Recent species, the morphology of this vessel and its impression is correlated with the type of respiratory structures present. There is also a slight depression just within and posterior of the left anterior shell muscle that corresponds to the position of the pericardium in living taxa. These same features are present in Floripatella and other fossil limpets. Lindberg and Squires (1990) described and illustrated Eocene Patelloida species from California and Oregon that have vessel impressions that are indicative of the presence of mantle gills. This is of particular interest because mantle gills are not found in any living Patelloida sp. today. Vessel impressions are also found in some living and fossil fissurelloidean taxa; however, in this group, it is an impression of the anterior aorta rather than the circumpallial vessel.

F. rousseaui may represent the oldest direct observation of circulatory patterns and vein morphology. F. rousseaui is preserved as a steinkern showing a horseshoe-shaped muscle scar that is open posteriorly and anteriorly (Fig. 6). The left and right portions of the muscle scar are divided into discrete but continuous bundles and are connected at their posterior ends by a thin pallial line. Anteriorly, the muscles are connected by a bulbous pallial line along which smaller muscle scars are visible. Immediately behind the posterior opening in the attachment muscles is a Y-shaped structure which extends from the center of the pallial line and gives rise to two branches that separate and extend towards the shell edge. Immediately in front of the main branch and enclosed within the muscle scar is the remnant of an elongated depression.

Although Yochelson (1988) considers this specimen to represent the earliest representative of the Patellogastropoda, I would argue that the Y-shape structure on the posterior margin of the steinkern represents the efferent mantle vessel, probably homologous with the circumpallial veins of the Pleurotomarioidea, Haliotoidea, Fissurelloidea, and Patellogastropoda. The size and morphology are similar to those described above in living and fossil patellogastropod taxa, and the depression into which the Y-shaped structure opens is possibly the pericardium depression. These depressions are also common in patellogastropod taxa. The position of the Y-shaped structure and its 


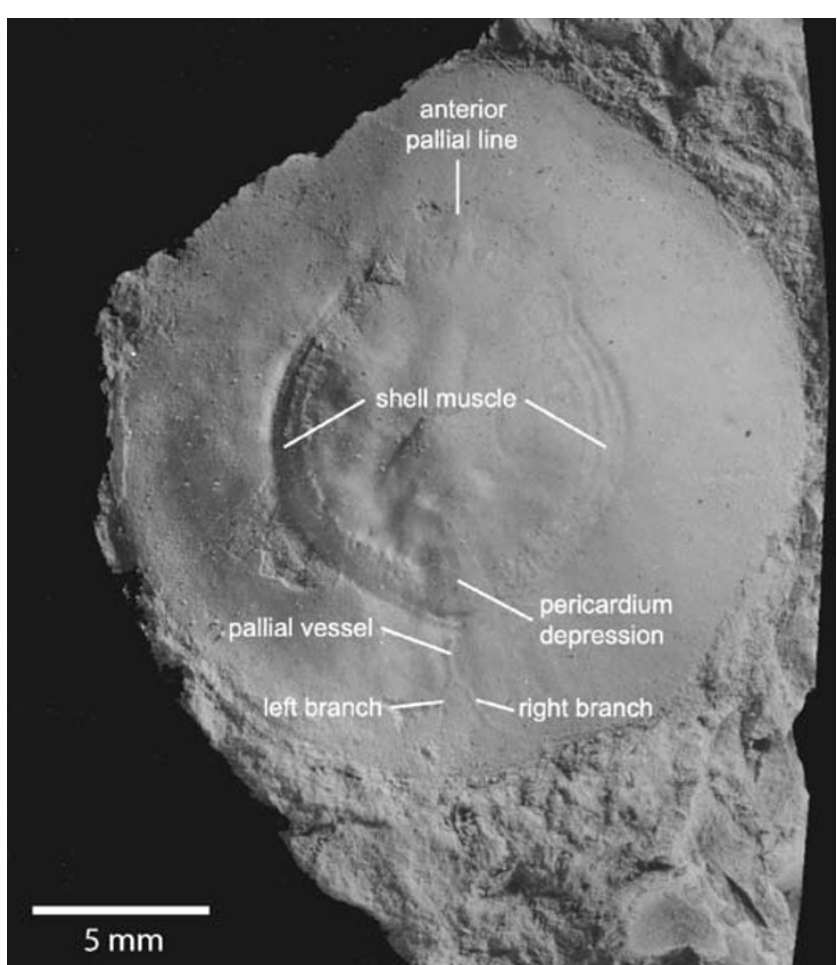

Fig. 6 F. rousseaui Yochelson 1988. Middle Ordovician; Utah, USA. Putative pallial vessel impression and pericardium depression

association with a posterior depression would require that $F$. rousseaui be an untorted mollusk and possibly a monoplacophoran with a continuous muscle band. If this interpretation is correct, it also suggests that consolidation of the mantle vessels and a reduction in the number of atria occurred one or more times in early conchiferan evolution and that only one lineage of monoplacophorans - the one having multiple paired muscle bundles-survived into the Recent.

\section{Habitat}

In the literature, Paleozoic monoplacophorans have been associated with a wide range of habitats. Although Horný (1963) concluded that most Paleozoic species lived on soft sediments in shallow epicontinental seas, Paleozoic taxa have also been found in association with stromatolites, where they are thought to have been algal/bacterial grazers in shallow marine environment of varying energy regimes. They have also been reported from Silurian hydrothermal vents (Little et al. 1997).

Stuber and Lindberg (1989) examined the depositional environments reported in over 150 publications listing the presence of Paleozoic Monoplacophora. The results are summarized in Fig. 7. In the Cambrian, monoplacophorans appear to have been well represented in intertidal (Facies 1) and shallow nearshore environments (Facies 2; Sepkoski 1987). In these habitats, they were associated with archaeocyathids, calcareous cyanobacteria, algal mud mounds, and stromatolites. In the Ordovician, monoplacophorans continued to be well represented in Facies 1 and 2, where they were associated with stromatolites, lithified calcareous substrates, algal mats, and erect benthic algae. However, unlike the Cambrian, Ordovician monoplacophorans were better represented in deeper offshore environments where they are associated with softer, muddier substrates. The Silurian and Devonian Periods were data-poor, as many of the specimens appeared to have been transported before final deposition. However, there was a clear absence of taxa from both Facies 1 and 2 during the mid-Paleozoic. These data support the hypothesis that during the Paleozoic, Monoplacophora moved from onshore to offshore habitats (Jablonski et al. 1983) and remained hidden in the deep sea until their discovery in the laboratory in 1956 (Lemche and Wingstrand 1959).

Living Monoplacophora show a similar diversity of habitats, occurring on deep sea oozes as well as on a variety of mud, silt, sand, and gravel sediments. They have also been found attached to ferromanganese and phosphorite nodules, stones, and boulders. Based on stomach contents, monoplacophorans appear to be benthic feeders taking in radiolarians, bacteria, foraminiferans, diatoms, polychaetes, and sponges. Bacterial endosymbionts have been reported in the mantle edge, the tips of gills, the lateral foot sides, and on the head and postoral tentacles of L. antarctica and Laevipilina theresae (Haszprunar et al. 1995). The bacteria were found between epidermal microvilli and aggregated within bacteriocytes (Haszprunar and Schaefer 1997a).

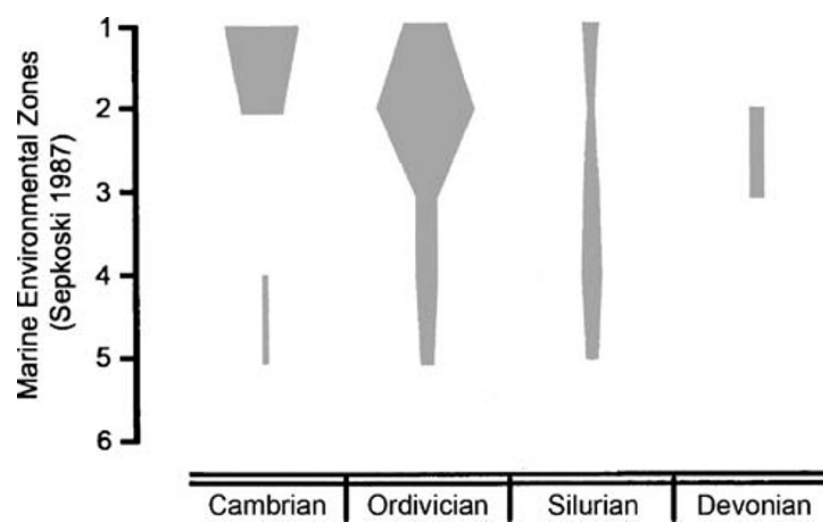

Fig. 7 Early Paleozoic distribution of Monoplacophora (Tryblidacea) across Sepkoski's (1987) environmental zones. Zone 1 nearshore (tidally influenced); Zone 2 nearshore (subtidal); Zone 3 offshore (turbulent); Zone 4 middle shelf (below wave base); Zone 5 shelf edge; Zone 6 deep water. Data compiled from over 150 publications listing the occurrence of Monoplacophora in Early Paleozoic facies (Stuber and Lindberg 1989) 
While the popular "living fossil" view of Monoplacophora presumes that they found refuge in the abyssal depths $(2,000-6,000 \mathrm{~m})$ of the ocean and in trenches, more than $60 \%$ of living species occur on continental shelves and in the adjacent bathyal zone (200-2,000 m; Fig. 8). In addition to a marked change in diversity patterns at the transition between bathyal and abyssal depths, there is also a dramatic change in monoplacophoran shell size here (Fig. 8). Above $2,500 \mathrm{~m}$, diversity increases quickly and peaks at depths between 500 and $1,000 \mathrm{~m}$. The mean size of the monoplacophoran species that make up this diversity is less than $5 \mathrm{~mm}$ in length, and the variance is relatively small. Below 2,500 m, mean size is greater than $10 \mathrm{~mm}$, and the variance substantially increases (Fig. 8). These patterns occur because both large species and small species are present at abyssal depths, whereas only small-bodied taxa are found in the bathyal zone. Diversity in the abyssal zone is also relatively flat compared to the bathyal zone. When the body size of living monoplacophorans is compared to size distributions from the Early Paleozoic (Stuber and Lindberg, unpub.), only living monoplacophorans living in the hadal zone $(>6000 \mathrm{~m})$ are comparable, although the mean size of the Paleozoic taxa is well within one standard deviation of the mean size of most living abyssal species (Fig. 8).

\section{Summary}

"Presumably it [Neopilina] originated from an ancestor inhabiting shallow water Cambrian-Devonian epicontinental seas and has been conserved in the abyss up to this day in a reasonably unchanged form." (Menzies et al. 1959: 169).

Fig. 8 Smoothed bathymetric species diversity curve (left axis) and size distribution (right axis) of living Monoplacophora species. Size data are mean size by $500 \mathrm{~m}$ bin \pm standard deviation. Solid circles are living species; open circle $=$ mean size and standard deviation for Early Paleozoic taxa. Recent data from Haszprunar (2008) and Schwabe (2008); fossil data from Stuber and Lindberg (unpub.)
Fifty years after Menzies et al. made the above statement, there are 29 additional described species and a body of work examining their anatomy using the latest methods and techniques. Additional fossil specimens have also been discovered and described, and what was once thought to be a possible missing link between annelid worms and mollusks now appears to be a highly specialized branch on the molluscan tree that tells us little about the ancestral mollusk condition.

One of the important remaining questions is, when did these unique characters appear in the Monoplacophora? For example, the multiple paired muscle scars are a diagnostic character of both fossil and living Monoplacophora, and this arrangement provides space for the placement of the kidneys in the roof of the mantle groove and the related functioning of the gills as ventilators rather than respiratory surfaces. Was this a feature of Early Paleozoic taxa or a subsequent modification as they moved into deep water habitats? Would such an arrangement function in intertidal habitats of the Paleozoic? Questions like these go to the heart of the idea of "conserved" character states versus subsequent change during their hiatus from the fossil record.

While many of the characters discussed above appear to have resulted from changes in developmental timing, it is difficult to determine if they were correlated or separate events and whether they are of Paleozoic or later origin. In other molluscan groups, there is evidence that some developmental changes within specific cell lineages will have ramifications for later development events (Moor 1983; van den Biggelaar and Haszprunar 1996; van den Biggelaar et al. 1997; Dictus and Damen 1997; Lindberg and Guralnick 2003). Developmental studies of Monoplacophora will be critical in providing insights into this

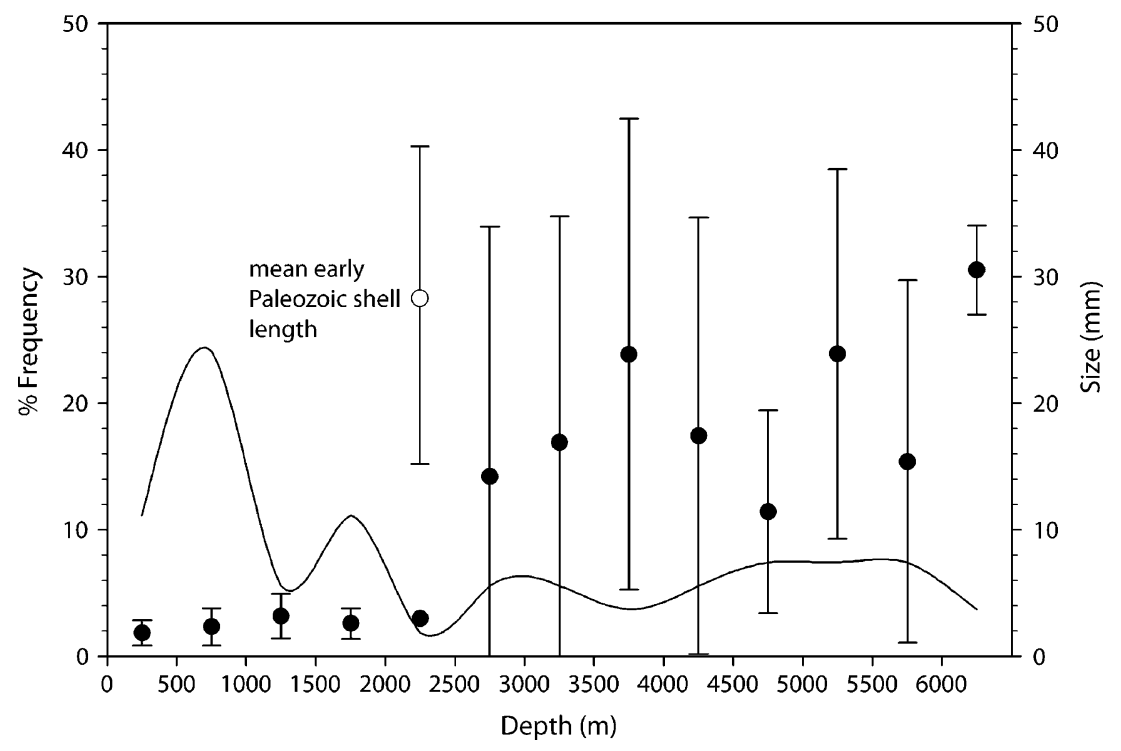


question. However, the methodological obstacles of doing developmental work on free-spawning mollusks that occur at a minimum depth of $175 \mathrm{~m}$ are formidable.

While much work remains to be done to further resolve the monoplacophoran's position on the molluscan Tree of Life, there also needs to be recognition of the innovative and integrative research approaches that these curious animals have attracted. J. B. Knight (1952), who would interpreted monoplacophorans as non-torted, primitive mollusks and grouped them with the chitons and aplacophorans, did this by integrating stratigraphic data from the fossil record with both anatomical and functional studies of living taxa and ontogenetic data from developmental studies. He then worked back through time, what he referred to as "climbing down the family tree," using data from living taxa to incorporate less well-known extinct forms into his evolutionary scenario. From these reconstructions, he then moved to other branches and reclimbed his tree looking for concurrence of characters across his evolutionary scenario. Four years after Knight's innovative use of paleontological and neontological data to construct hypotheses of molluscan evolution, the discovery of $N$. galatheae validated his interpretation of Tryblidium, and invertebrate zoologists and malacologists anointed the newly discovered limpets from the abyssal plains off Costa Rica as a living fossil. While the living fossil designation remains ambiguous, the methodology that J. B. Knight and others have employed in the study of these unique mollusks has been validated.

Acknowledgments I thank W. Ponder and G. Haszprunar for countless critical discussions of molluscan relationships, R. Stuber for her detailed study of monoplacophoran fossil occurrences, the late M. Taylor for preparing Figs. 3-5, the late E. Yochelson for sharing Floripatella with me, P. Wagner for specimen data, and G. Haszprunar and three anonymous reviewers for helpful criticism of the manuscript. The Paleobiology Database (http://paleodb.org/), assembled by J. Alroy and contributors, provided data and resources for the preparation of this paper, for which I am most grateful. I also thank D. Prothero and N. Eldredge for the opportunity to contribute to this volume. This is UC Museum of Paleontology contribution number 1991.

Open Access This article is distributed under the terms of the Creative Commons Attribution Noncommercial License which permits any noncommercial use, distribution, and reproduction in any medium, provided the original author(s) and source are credited.

\section{References}

Alberch P, Gould S, Oster G, Wake D. Size and shape in ontogeny and phylogeny. Paleobiology. 1979;5:296-317.

Angelin N, Lindström G. Fragmenta Silurica e Dono Caroli Henrici Wegelin. Opus Studio Nicolai Petri Angelin Inchoatum Jussu et Impensis Academiae Regiae Scientarum Suecicae. 1880;1-60.

Bouchet P, McLean J, Warén A. Monoplacophorans in the North Atlantic. Oceanol Acta. 1983;6:117-8.
Butterfield N. Hooking some stem-group "worms": fossil lophotrochozoans in the Burgess Shale. Bioessays. 2006;28:1161-6. doi:10.1002/bies.20507.

Caron J, Scheltema A, Schander C, Rudkin D. A soft-bodied mollusk with radula from the Middle Cambrian Burgess Shale. Nature. 2006;442:159-63. doi:10.1038/nature04894.

Cleland H. Further notes on the Calciferous (Beekmantown) formation of the Mohawk valley, with descriptions of new species. Bull Am Paleontol. 1903;4:29-50.

Conway Morris S, Peel J. Articulated halkieriids from the Lower Cambrian of north Greenland. Nature. 1990;345:802-5. doi:10.1038/345802a0.

Dall W. Phylogeny of the Docoglossa. Proc Acad Nat Sci Philadelphia. 1893;1893:285-7.

Dautzenberg P, Fischer H. Dragages effectués par l'Hirondella et par la Princesse-Alice, 1888-1896: 1, Mollusques Gastéropodes. Mem Soc Zool Fr. 1896;9:395-498.

Dautzenberg P, Fischer H. Dragages effectués par l'Hirondella et par la Princesse-Alice, 1888-1896. Mem Soc Zool Fr. 1897;10:139-234.

de Beer G. Embryos and ancestors. Revised edition. Oxford: Clarendon; 1951. p. 1-159.

Dictus W, Damen P. Cell-lineage and clonal contribution map of the trochophore larva of Patella vulgata (Mollusca). Mech Dev. 1997;62:213-26. doi:10.1016/S0925-4773(97)00666-7.

Erben H, Flass G, Siehl A. Über die Schalenstruktur von Monoplacophoren. Abh Akad Wissens Lit, Mainz. Math-Natur Kl. 1968;1968:1-24.

Giribet G, Okusu A, Lindgren A, Huff S, Schrödl M, Nishiguchi M. Evidence for a clade composed of mollusks with serially repeated structures: monoplacophorans are related to chitons. Proc Natl Acad Sci USA. 2006;103:7723-8. doi:10.1073/pnas.0602578103.

Golikov A, Starobogatov Y. Questions of phylogeny and systematics of prosobranch gastropods. Tr Zool Inst Akad Nauk SSSR. 1988; 176:4-77. in Russian.

Gonor J. Monoplacophora, first edition, reproduction of marine invertebrates vol. V. New York: Academic; 1979. p. 87-93.

Götting K. Origin and relationships of the Mollusca. Zeit Zool Syst Evolutionsforsch. 1980;18:24-7.

Gould S. Ontogeny and phylogeny. Massachusetts: Belknap; 1977. p. $1-501$.

Haszprunar G. On the origin and evolution of major gastropod groups, with special reference to the Streptoneura (Mollusca). J Moll Stud. 1988;54:367-441. doi:10.1093/mollus/54.4.367.

Haszprunar G. The first mollusks-small animals. Boll Zool. 1992;59:1-16.

Haszprunar G. Is the Aplacophora monophyletic? A cladistic point of view. Am Malacol Bull. 2000;15:115-30.

Haszprunar G. Monoplacophora (Tryblidia), first edition, phylogeny and evolution of the mollusca. Berkeley: University of California Press; 2008. p. 97-104.

Haszprunar G, Schaefer K. Monoplacophora, microscopic anatomy of invertebrates vol. 6B: mollusca II. New York: Wiley-Liss; 1997a. p. $415-57$.

Haszprunar G, Schaefer K. Anatomy and phylogenetic significance of Micropilina arntzi (Mollusca, Monoplacophora, Micropilinidae fam.nov.). Acta Zool. 1997b;77:315-34.

Haszprunar G, Schaefer K, Warén A, Hain S. Bacterial symbiosis in the epidermis of an Antarctic neopilinid limpet (Mollusca, Monoplacophora). Phil Tran Roy Soc London. Ser B. 1995;347:181-5.

Haszprunar G, Schander C, Halanych K. Relationships of higher molluscan taxa, First Edition, Phylogeny and Evolution of the Mollusca. Berkeley: University of California Press; 2008. p. 19-32.

Hedegaard C, Wenk R. Microstructure and texture patterns of mollusk shells. J Moll Stud. 1998;64:133-6. doi:10.1093/mollus/64.1.133.

Hickman C, Lindberg D. Perspectives on molluscan phylogeny, Mollusks. Notes for a short course. Univ Tennessee Dept Geol Sci. Stud Geol (Tulsa). 1985;13:13-6. 
Horný R. Lower Paleozoic Bellerophontina (Gastropoda) of Bohemia. Sborni'k Geol Ved. 1963;2:57-164.

Hyman L. The invertebrates vol. VI. Mollusca I, first edition. New York: McGraw- Hill; 1967. p. 1-792.

Jablonski D, Sepkoski J, Bottjer D, Sheehan P. Onshore-offshore patterns in the evolution of Phanerozoic shelf communities. Science. 1983;222:1123-5. doi:10.1126/science.222.4628.1123.

Knight J. Primitive fossil gastropods and their bearing on gastropod classification. Smithson Misc Collect. 1952;117:1-56.

Knight J, Yochelson E. Monoplacophora, treatise on invertebrate paleontology. Mollusca 1, first edition. Lawrence: Geological Society of America and University of Kansas Press; 1960. p. I77-84.

Lauterbach K-E. Gedanken zur Entstehung der mehrfach paarigen Exkretionsorgane von Neopilina (Mollusca, Conchifera). Z zool Sys Evolutionsforsch. 1983;21:38-52.

Lemche H. A new living deep-sea mollusk of the Cambrio-Devonian class Monoplacophora. Nature. 1957;179:413-6. doi:10.1038/ $179413 \mathrm{a} 0$.

Lemche H. (1959a) Molluscan phylogeny in the light of Neopilina. Proc 15th Intern Cong Zool, London: 380-381.

Lemche H. (1959b) Protostomian interrelationships in the light of Neopilina. Proc 15th Intern Cong Zool, London: 381-389.

Lemche $\mathrm{H}$, Wingstrand $\mathrm{K}$. The anatomy of Neopilina galatheae Lemche, 1957. Galathea Rep. 1959;3:9-71.

Lindberg D. Anatomy, systematics, and evolution of brooding acmaeid limpets. Ph. D. dissertation, Biology, University of California: Santa Cruz, 1983;1-277.

Lindberg D. Gastropods: The neontological view. Heterochrony in Evolution: An Interdisciplinary Approach. New York: Plenum Press; 1988. p. 197-216.

Lindberg D, Guralnick R. Phyletic patterns of early development in gastropod mollusks. Evol Dev. 2003;5:494-507. doi:10.1046/ j.1525-142X.2003.03055.x.

Lindberg D, Ponder W. An evolutionary tree for the Mollusca: branches or roots? First edition, origin and evolutionary radiation of the Mollusca. Oxford: Oxford University Press; 1996. p. 67-75.

Lindberg D, Ponder W. The influence of classification on the evolutionary interpretation of structure - a re-evaluation of the evolution of the pallial cavity of gastropod mollusks. Org Divers Evol. 2001;1:273-99. doi:10.1078/1439-6092-00025.

Lindberg D, Squires R. Patellogastropods (Mollusca) from the Eocene Tejon Formation of southern California. J Paleontol. 1990;64:578-87.

Little C, Herrington R, Maslennikov V, Morris N, Zaykov V. Silurian hydrothermal vent community from the southern Urals, Russia. Nature. 1997;385:146-8. doi:10.1038/385146a0.

Lowenstam H. Recovery, behaviour, and evolutionary implications of live Monoplacophora. Nature. 1978;213:231-2.

McKinney M, McNamara K. Heterochrony. The evolution of ontogeny, first edition. New York: Plenum; 1991. p. 1-437.

Mclean J. A new genus and species of Monoplacophora from the continental shelf of southern California. Contr Sci Nat Hist Mus Los Angeles Co. 1979;307:1-19.

Meenakshi V, Hare P, Watabe N, Wilbur K, Menzies R. Ultrastructure, histochemistry, and amino acid composition of the shell of Neopilina. Anton Bruun Rept 2 Sci Res Southeast Pacific Exped: 1970;3-12.

Menzies R, Ewing M, Worzel J, Clarke A. Ecology of the recent Monoplacophora. Oikos. 1959;10:168-82. doi:10.2307/3565144.

Moor B. Organogenesis. Mollusca, Vol. 3, Development, First Edition. New York: Academic; 1983. p. 123-77.

Moskalev L, Starobogatov Z, Filatova Z. New data on the abyssal Monoplacophora from the Pacific and South Atlantic oceans. Zool Zh. 1983;62:981-95.

Parkhaev P. Phylogenesis and the system of the Cambrian univalved mollusks. Paleon J. 2002;36:25-36.
Parkhaev P. The early Cambrian radiation of Mollusca, first edition, phylogeny and evolution of the Mollusca. Berkeley: University of California Press; 2008. p. 33-70.

Peel J. The classes Tergomya and Helcionelloida, and early molluscan evolution. Gronlands Geologiske Undersuch Bull. 1991;161:11-65.

Peel J, Horný R. Muscle scar and systemtic position of the lower Palaeozoic limpets Archininacella and Barrandicella gen. n. (Mollusca). J Czech Geol Soc. 1999;44:97-116.

Pojeta J, Runnegar B. The paleontology of rostoconch mollusks and the early history of the phylum Mollusca. US Geol Surv Prof Pap. 1976;968:1-88.

Ponder W, Lindberg D. Gastropod phylogeny: challenges for the 90's, first edition, evolutionary radiation of the Mollusca. Oxford: Oxford University Press; 1996. p. 135-54.

Ponder W, Lindberg D. Towards a phylogeny of gastropod mollusks - a preliminary analysis using morphological characters. Zool J Linn Soc. 1997;119:83-265. doi:10.1111/j.1096-3642.1997.tb00137.x.

Runnegar B. Early evolution of the Mollusca: the fossil record, first edition, evolutionary radiation of the Mollusca. Oxford: Oxford University Press; 1996. p. 77-87.

Russell-Hunter W, Brown S. Ctenidial number in relation to size in certain chitons, with a discussion of its phyletic significance. Biol Bull. 1965;128:508-21. doi:10.2307/1539910.

Salvini-Plawen L. Zur Morphologie und Phylogenie der Mollusken: Die Beziehungen der Caudofoveata und der Solenogastres als Aculifera, als Mollusca und als Spiralia. Zeit Wissenschaf Zool Leipzig. 1972;184:205-394.

Salvini-Plawen L. On the origin and evolution of the Mollusca. Atti dei convegni Lincei. 1981;49:235-93.

Salvini-Plawen L. Early evolution and the primitive groups. First edition, the mollusca, evolution, 10. Orlando: Academic; 1985. p. 59-150.

Salvini-Plawen L. Origin, phylogeny and classification of the phylum Mollusca. Iberus. 1991;9:1-33.

Salvini-Plawen L, Steiner G. Synapomorphies and pleisomorphies in higher classification of Mollusca, first edition, origin and evolutionary radiation of the Mollusca. Oxford: Oxford University Press; 1996. p. 29-51.

Schaefer K, Haszprunar G. Organisation and fine structure of the mantle of Laevipilina antarctica (Mollusca, Monoplacophora). Zool Anz. 1997;236:13-23.

Schmidt W. Bemerkungen zur Schalenstruktur. von Neopilina galatheae. Galathea Rep. 1959;3:73-8.

Schwabe E. A sumamry of reports of abyssal and hadal Monoplacophora and Polyplacophora (Mollusca). Zootaxa. 2008;1866:205-22.

Seguenza G. Studi stratigrafici sulla formazione Pliozena dell Italia meridionale. Elenco dei Cirripedi e Molluschi dell Antico Plioceno. Boll Comm Geol Ital. 1876;7:259-71.

Sepkoski J. Environmental trends in extinction during the Paleozoic. Science. 1987;235:64-6. doi:10.1126/science.11539724.

Sepkoski J. A compendium of fossil marine animal genera. Bull Am Paleontol. 2002;363:1-560.

Signor P. Gastropod evolutionary history. Mollusks, Notes for a Short Course. Univ Tennessee, Dept Geol Sci. Stud Geol (Tulsa). 1985;13:157-73.

Starobogatov Y. Syst Early Paleoz Monoplacophora. Paleont J. 1970;10:293-302.

Steinböck O. Origin and affinities of the lower Metazoa. First Edition, The Lower Metazoa. Berkeley: University of California Press; 1963. p. 45-54.

Stuber R, Lindberg D. Is the radula of living monoplacophorans primitive? Abstr Progr Ann Mtg. Geol Soc Am. 1989;21:A289.

Vagvolgyi J. On the origin of mollusks, the coelom, and coelomic segmentation. Syst Zool. 1967;16:153-68. doi:10.2307/2411408.

van den Biggelaar J, Haszprunar G. Cleavage patterns and mesentoblast formation in the Gastropoda: an evolutionary perspective. Evol. 1996;50:1520-40. doi:10.2307/2410889. 
van den Biggelaar J, Dictus A, Van Loon A. Cleavage patterns, celllineages and cell specification are clues to phyletic lineages in Spiralia. Semin Cell Dev Biol. 1997;8:367-78. doi:10.1006/ scdb.1997.0161.

Vinther J, Nielsen C. The Early Cambrian Halkieria is a mollusk. Zool Scr. 2005;34:81-9. doi:10.1111/j.1463-6409.2005.00177.x.

von Zittel K. Text-book of Palaeontology, vol. 1. In: Eastman C, editor. Second edition. London: Macmillan; 1913. p. 1-839.

Waller T. Origin of the molluscan class Bivalvia and a phylogeny of the major groups, First Edition, Bivalves: an eon of evolution. Alberta: University of Calgary Press; 1998. p. 1-45.

Warén A. Neopilina goesi, a new Caribbean monoplacophoran dredged in 1869. Proc Biol Soc Wash. 1988;101:676-81.

Warén A, Bouchet P. Laevipilina rolani, a new monoplacophoran from off southwestern Europe. J Moll Stud. 1990;56:449-53. doi:10.1093/mollus/56.3.449.

Warén A, Hain S. Laevipilina antarctica and Micropilina arntzi, two new monoplacophorans from the Antarctic. Veliger. 1992;35:165-76.
Wenz W. Hanbuch der Palaozoologie (Herausgegaben v. Schindewolf) Band 6, Gastropoda, Teil 1, Allgmeiner Teil und Prosobranchia (pars.), 1938;1-240.

White K. Mytilus. First edition, L.M.B.C. Memoirs on Typical British Marine Plants and Animals. Liverpool: University of Liverpool Press; 1937. p. 1-117.

Whitfield R. Observations on some imperfectly known fossils from the Calciferous Sandrock of Lake Champlain, and descriptions of several new forms. Bull Am Mus Nat Hist. $1889 ; 2: 41-63$.

Wingstrand K. On the anatomy and relationships of Recent Monoplacophora. Galathea Rep. 1985;16:7-94.

Yochelson E. A new genus of Patellacea (Gastropoda) from the Middle Ordovician of Utah: the oldest known example of the superfamily. N Mex Bur Mine Min Res Mem. 1988;44:195200.

Zeldrich M. Beyond heterochrony: the evolution of development, first edition. New York: Wiley-Liss; 2001. p. 1-392. 